\title{
Internet and Social Networks: On the Need to Be Online
}

\author{
Caetano da Providência Santos Diniz, Elisângela Cláudia de Medeiros Moreira \\ Departament of Psychology, State University of Pará, Belém, Brazil \\ Email: caediniz@hotmail.com
}

Received 26 February 2015; accepted 1 April 2015; published 3 April 2015

Copyright (C) 2015 by authors and Scientific Research Publishing Inc.

This work is licensed under the Creative Commons Attribution International License (CC BY). http://creativecommons.org/licenses/by/4.0/

c) (i) Open Access

\begin{abstract}
The advent of internet has brought human relations into focus. The tools offered by the technology facilitate and increase contact between people and provoke changes in the way people relate to one another. The need to be online has become one of the main objectives of online interaction. Internet users are capable of creating true online relationships, showing affection, establishing friendships or even entering into conflict. They are also capable of maintaining an online life where communication finds a meaning in itself, and whose only aim is to be in contact with someone else.
\end{abstract}

\section{Keywords}

Internet, Technology, Online Sociability

\section{Introduction}

The objective of this article is to reflect on relationships mediated by the Internet focusing on the new necessity that this technology has created into its users that is to be in permanent contact, and emphasizing the subjective aspects related to it, such as the process of identification and affective exchanges. According to Lévy (1996) the word virtual originated from the Latin word virtualis meaning strength, power. It refers to the idea of possibility; in other words, something that can be, but has not been, yet. When it comes to relationship resulting from the Internet, however, one cannot use this term in its literal sense, because the relationships that occur under these circumstances here, cannot be considered as mere "possibilities". They are as real as those occurring in the offline world.

\section{The Real and Virtual in the Internet User Experience}

According to Matos-Silva, Abreu and Nicolaci-da-Costa (2012), cyberspace has characteristics that are unique 
to the communities. The difference is in the use of a specific technology that permits that in the "virtual world" interaction occurs from different places and, sometimes, different moments. According to Rheingold (1996: p. 16), these experiences are not so different from those offline, despite the physical distance: "Virtual community people do anything that can be done by people in real life, although disconnected from their bodies". He notes that virtual communities are social aggregations that surge in the internet for a certain period. These aggregations raise public discussions from interactions that present sufficient emotion and form real social relation networks.

However, this aspect should not be considered an Internet peculiarity, because the telephone had already permitted such interaction from different places, and in the case of answering machines, at different moments. The issue is not in space and time, but in the fact that Internet favors sociability in a way never seen before, to the extent that 1) it offers spaces to form new relationships; 2) raises interactions from "someone to someone"; 3 ) encourages and enables interaction from "many-to-many people".

The web users tend to gather in communities in order to share common interests, experiences and opinions, receive feedback by publishing items capable of transmitting interests, sense of humor, daily activities etc. The most popular current tools, such as Instagram, Twitter and Facebook are examples of spaces suited for such practices. As stated by Pimentel and Diniz (2014: p. 2134):

Posting are made to see people reaction, to "provoke" the other individual, to receive feedback and possible comments of affection, repulse, agreement or disagreement. Joining the social networks allows people to follow someone who is loved or feared, or anyone to whom affections are directed. The contacts are frequently posting comments that reveal his/her sense of humor, attitudes, activities as if writing a virtual public diary.

These authors state that the experience also serves two objectives, self-exposition and the process of identification. The postings permit the users to be recognized by other people by offering constant feedback on themselves, their attitudes, enabling them to see themselves as if in a mirror. Thus, according to Pimentel \& Diniz (2014: p. 2134):

In such scenario, self-expression becomes an exercise of identification where someone else takes a leading place, for that is the one that confirms us, making us see ourselves through different prisms, discovering and constructing nuances, setting forth ways of being, expressing, reacting, receiving or rejecting, attitudes that until then we had not been aware of.

\section{Need to Be Online}

The need to be in contact comes with the evolution of new tools of social interaction characterizing the experience of heavy internet users, since the expansion of the web in the 90's with the massification of the personal computer (pc), and the current use cell-phone applicatives connected to the web providing more mobility to its use (Diniz, 2014). This need is perceived by the anxiety caused when someone forgets to bring his/her cell phone all the way to the anguish and despair they feel, when, for technical reasons their phone connections fails.

Internet Addiction Disorder - IAD: or the Compulsive Use of Internet is characterized, like many other dependencies, by losses in the individual's performance compromising one's daily activities, physical and psychological health. There has been some studies on the subject by Moreno et al. (2012) from the University of Wisconsin, USA, who calls attention to the positive correlation between depression and teenagers using the web. Also, by Reda et al. (2012) from the da University of Ain Shams, in Egypt, who also found correlation between the problematic use of the web and psychiatric morbidity among Egyptian teenagers; by Tong et al. (2010), from the University of Wuhan, in China who addressed the implications of the Compulsive Use of Internet to mental health and quality of life of its users.

However, the necessity of being constantly online does not happen only in those cases of internet addiction. Frequent users who do not face losses in their quality of life may incorporate Internet use in their daily life because they consider surfing the web a peculiar convenience, a need to be with a group. According to Diniz (2008), this interaction can assume several aspects such as:

1) The simple option to make contacts using the web. Meeting someone personally is not an issue, even when that is possible, in order words, when the geographical distance permits. In those cases, the written word and 
images fulfill satisfactorily the desire to interact. This aspect can also be observed with the advent of cell-phone applicative that allows instant messaging, such as the Whatsapp, dispensing the users of making phone calls who prefer to text messages in such way the written language seems to have been incorporated more strongly in the users' daily life (Pimentel \& Diniz, 2014).

This type of tool consolidates the current tendency to be always connected to someone else, in other words, one does not have to turn off the notebook or finish a phone call. The information and communication age has reached a higher level when the use of technology surpasses the need to transmit information considered important. Instead, the need to be in contact may be the only end to be achieved, while communication becomes the objective itself (Castells, 2006).

2) The expansion of possibilities to make new contacts. Each person ends up serving as a link to someone else, working as a knot in a weave connecting other knots, with their respective network of contacts. That shows one of the main missions of the Internet, which not only keeps old contacts, but quickly creates new ones.

3) Human need to get together is reinforced. One wishes to belong to a group, share opinions, interests, life style, etc. The process of identification also has this nuance so far as the other person is not seen as a mirror where I am capable of looking at it and recognize myself, but also to offer me safety so far as it satisfies my need to join. Allowing me to join something that I consider important and that characterizes me before other people in a way or another.

Considering the above, one may perceive a general factor present in all these aspects. As stated by Pimentel \& Diniz (2014: p. 2131): "It also represents the possibility of being permanently connected, continuously online. Its use becomes an element of strong affection, which means obtaining the attention of his/her peers through message texting".

The virtual space has the power to bring individuals together, regardless of where they are. This coming together seems to be legitimized with the exchange of conversation, where Internet users expose their affinities, exchange compliments, dream about the ideal match, create fantasies, intermediate sex, sigh when thinking about their achieved idealization and obtain from it a pleasant leisure activity (Perez, 2007: p. 20).

Finally, frequent message exchanges may give a sensation of someone's permanent presence, regardless of the distance, being possible to count on the help of images and videos to express affection that cannot often be expressed on a face to face basis considering that pressure for physical presence may inhibit manifestation of emotions.

\section{Conclusion}

Psychology needs to monitor cultural changes caused by technological advances. It should investigate social aspects and subjective impacts from web use, being important to describe and discuss the users' experiences without forgetting to understand the meanings that they give them, especially those items concerning need to be online, as well as the implications that it may bring to the individual's well-being or uneasiness.

\section{References}

Castells, M. A. (2006). Sociedadeem Rede (9th ed). São Paulo: Paz e Terra.

Diniz, C. (2014). A Escrita nas Redes Sociais e suas Implicações Subjetivas. Sócio-dialeto, Mato Grosso do Sul, 5, 1-12.

Diniz, C. P. S. (2008). Relacionamentos Humanos Mediadospelo Computador: As Experiências de Internautas Cadastrados no Site de Comunidades UOL K. Masters Thesis, Para: Universidade Federal do Para.

Lévy, P. (1996). O Que é o Virtual? São Paulo: Editora 34.

Matos-Silva, M. S., Abreu, R. A. S., \& Nicolaci-da-Costa, A. M. (2012). Como Satisfazer Nossas Necessidades de Interagir Online Emdiferentes Níveis de Intimidade? Um Estudosobre a Comunicaçãonas Comunidades Virtuais. Interaçãoem Psicologia, 16, 217-226. http://dx.doi.org/10.5380/psi.v16i2.24662.

Moreno, M., Jelenchick, L., Koff, R., \& Eickhoff, J. (2012). Depression and Internet Use among Older Adolescents: An Experience Sampling Approach. Psychology, 3, 743-748. http://dx.doi.org/10.4236/psych.2012.329112.

Pimentel, A., \& Diniz, C. (2014). Language Used in Social Networks: Creativity and Self-Expression. Psychology, 5, 21312137. http://dx.doi.org/10.4236/psych.2014.519215

Reda, M., Rabie, M., Mohsen, N., \& Hassan, A. (2012). Problematic Internet Users and Psychiatric Morbidity in a Sample of 
Egyptian Adolescents. Psychology, 3, 626-631. http://dx.doi.org/10.4236/psych.2012.38096.

Rheingold, H. (1996). A Comunidade Virtual. Lisboa: Gradiva.

Tong, Q., Zou, X., \& Tong, H. (2010). Analysis of Psychological Health and Life Qualities of Internet Addicts Using Structural Equation Model. Psychology, 1, 22-26. http://dx.doi.org/10.4236/psych.2010.11004 